\title{
Management of Enterocutaneous Fistulae: Challenges Facing the General Surgeon
}

\author{
Shemssie Shewmollo Bushira* \\ Senior surgical resident at Saint Paul's teaching referral hospital, Ethiopia
}

Submission: March 25, 2017; Published: August10, 2018

"Corresponding author: Shemssie Shewmollo Bushira, Senior surgical resident at Saint Paul's teaching referral hospital, Addis Ababa, Ethiopia; Email: shemssie@yahoo.com

\section{Introduction}

A fistula is an abnormal communication between two epithelialized surfaces. An enterocutaneous fistula (ECF) is a communication between the bowel lumen and the skin. Enteric fistulas represent difficult clinical complications, with significant morbidity and mortality. Even with the best available medical care, the mortality rate is as high as $10-30 \%$ in recent series. While the most common causes of enterocutaneous fistula in the developed countries are inflammatory bowel diseases and diverticular diseases, the main cause in the developing countries is due to postoperative complications of abdominal surgery.

\section{Etiologies of Enterocutaneous Fistulas}

The vast majorities of enterocutaneous fistulas ( 75 to $90 \%$ ) are iatrogenic in origin and commonly follow leakage from intestinal anastomosis, inadvertent enterotomy during laparotomy done for bowel obstruction, inflammatory bowel disease or operation complicated by adhesions. According to a study from Tanzania, Postoperative complication was the commonest cause of enterocutaneous fistulae in $91.3 \%$ of cases. Fistulas may occur in Crohn's disease, radiation enteritis, or extension of adjacent disease to normal bowel such as with malignant conditions [1-5]. In their 2 year prospective study involving a total $\mathrm{f} 25$ patients Prashant et al. [6] found typhoid ileal perforation and abdominal tuberculosis as the most common causes of fistula formation others found surgical misadventure as the most common cause [7].

\section{Classification of ECF}

Enterocutaneous fistulas are classified with regard to anatomy, etiology, physiology. The anatomic classification of enteric fistulas is based upon the segment of bowel from which it originates where as the physiologic classification is based on the volume of fistula output over $24 \mathrm{hrs}$. A fistula output of $>500 \mathrm{~mL} /$ day is taken as high and $<500 \mathrm{ml} /$ day as low output fistula [8]. In our study we will use this classification for ease and cost of measurement by this method. However, there are no collection devices in our set up to measure the exact amount of fistula output and as a result this technique has high error rate.

\section{Factors Affecting Fistula Closure}

Fistulas have the potential to close spontaneously; however there are factors negatively affecting fistula closure. These factors are often remembered by the mnemonic FRIEND which represents F=Foreign Body In The Fistula=Radiation Enteritis; I=Infection/Inflammation; E=Epithelialization of Fistulus Tract; N=Neoplasm And D=Distal Obstruction [9]. In addition, Nutritional status of the patient and fistula output are significant predictors of healing of ECF and mortality.

\section{Evaluation of Patients with ECF}

Patients should have nutritional assessment which mainly focuses on biochemical assessment, and most of the biochemical data focus on albumin [8]. Complete blood count, serum electrolytes, abdominal ultrasound, HIV test and test for co morbidities when indicated are the other commonly done tests to assess patients with enterocutaneous fistulas $[4,5,9]$.

\section{Initial Management of ECF}

Once diagnosis of fistula established, decision has to be made as to operate urgently or go for conservative management. Surgery is initially necessary in cases of acute abdomen such as septic peritonitis, bowel obstruction or underlying concomitant urgent surgical pathology. Patients need initial phase of stabilization where electrolytic balance, circulating volume and reduction of fistula output facilitated. This phase is followed by nutritional support and defining anatomy and definitive intervention [10-12]. The optimal timing for elective definitive surgical intervention has not been prospectively studied and in retrospective studies, the data is mixed. As about half of fistulae will spontaneously close within 3 weeks, this seems the minimum reasonable period for observation [13]. In their 10 years study involving a total of 83 ECF patients. Deepa Taggarshe found no statistically significant difference in outcomes between conservative and surgical management of ECF [11].

\section{Complications of ECF}

Malnutrition is the most common complication of enterocutaneous fistula. Sepsis and electrolyte imbalance are 
other major complications. Skin changes add considerably to the morbidity of patients [12].

\section{References}

1. William Schecter (2012) Principles of management of enteric fistulas.

2. Michael J Zinner, Stanley W Ashley (2007) Maingot's abdominal operations. In: (11 ${ }^{\text {th }}$ edn) 205(6): 3-4.

3. Bryant RA (2000) Acute and Chronic Wounds. In: ( $4^{\text {th }}$ edn), St Louis: Mosby, USA.

4. PL Chalya, M Mchembe, JM Gilyoma, JB Mabula, B.Mawala, et al. (2010) Enterocutaneous fistula: a Tanzanian experience in a tertiary care hospital 15(2).

5. Mathew Varghese (2008) General surgery principles and international practice. $\left(2^{\text {nd }}\right.$ edn $)$.

6. Prashant Mukadam, Shakib Masu, Atisha M Patel (2014) Clinical Profile of Postoperative Enterocutaneous Fistulas. GCSMC J Med Sci 3(1).

7. Manal Badrasawi, Suzana Shahar, Ismail Sagap (2015) Nutritional Management in Enterocutaneous Fistula. What is the evidence? Malays J Med Sci 22(4): 6-16.

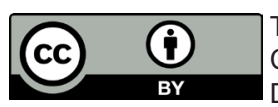

This work is licensed under Creative Commons Attribution 4.0 License DOI: 10.19080/ARGH.2018.10.555778
8. Prakash Kumar, Nanda K. Maroju, Vikram Kate (2011) Enterocutaneous Fistulae: Etiology, Treatment, and Outcome - A Study from South India. Saudi J Gastroenterol. 17(6): 391-395.

9. F Charles Brunicardi, Dana K Andersen, Timothy R Billiar, et al. Schwartz's principles of surgery. In: (10th edn).

10. Daniel E Wainstein, Victoria Tüngler, Constanza Ravazzola, Osvaldo Chara (2011) Management of external small bowel fistulae: challenges and controversies confronting the general surgeon. Int J Surg 9(3): 198-203.

11. Deepa Taggarshe, Daniel Bakston, Michael Jacobs, Alasdair McKendrick, Vijay K Mittal (2011) Management of enterocutaneous fistulae: A 10 years experience. Int J Surg. 9(3):198-203.

12. Arti Mitra, Unmed Chandak, Prashant Agarwal, Manish Singh, Ritesh Satarda (2015) Study of enterocutaneous fistula. JEBMH. 2(12): 18231830.

13. Stephen MC, Steven TB (2012) Surgery: evidence based practice USA.

\section{Your next submission with JuniperPublishers will reach you the below assets}

- Quality Editorial service

- Swift Peer Review

- Reprints availability

- E-prints Service

- Manuscript Podcast for convenient understanding

- Global attainment for your research

- Manuscript accessibility in different formats

( Pdf, E-pub, Full Text, audio)

- Unceasing customer service

Track the below URL for one-step submission https://juniperpublishers.com/online-submission.php 